\title{
A fluorimetric method for the measurement of pyridoxal and pyridoxal phosphate in human plasma and leucocytes, and its application to patients with sideroblastic marrows
}

\author{
GILLIAN P SMITH, DIANA SAMSON, ${ }^{*}$ TIMOTHY J PETERS \\ From the Division of Clinical Cell Biology and *Section of Haematology, MRC Clinical Research Centre, \\ Harrow, Middlesex
}

SUMMARY A highly sensitive fluorimetric assay for the measurement of pyridoxal and pyridoxal phosphate in biological tissues is described. The method involves the enzymic hydrolysis of pyridoxal phosphate to pyridoxal. The pyridoxal (free or total) is separated on an anion-exchange column, concentrated by cation-exchange chromatography and reacted with potassium cyanide under slightly alkaline conditions to form 4-pyridoxolactone, a highly fluorescent compound. The method is applied to the measurement of pyridoxal, pyridoxal phosphate and total pyridoxal in plasma and neutrophils from control subjects and patients with sideroblastic marrow and identified the patient with pyridoxine-responsive sideroblastic anaemia.

Pyridoxal 5'-phosphate, the coenzyme form of pyridoxine (vitamin $\mathrm{B}_{6}$ ) plays an important role in numerous biochemical reactions. The pyridoxal content of tissues is regulated by a number of factors including plasma membrane transport, ${ }^{1}$ phosphorylation of free pyridoxal ${ }^{2}$ and by binding of the coenzyme to apoprotein. ${ }^{34}$ Pyridoxal phosphate concentrations are controlled by pyridoxal phosphate phosphatases $^{56}$ which hydrolyse unbound pyridoxal phosphate to pyridoxal.

Although pyridoxine deficiency has been implicated in a number of diseases, including sideroblastic anaemia, ${ }^{78}$ alcoholism $^{910}$ and liver disease ${ }^{11}$ detailed investigations of the plasma and tissue pyridoxal and pyridoxal phosphate concentrations are not generally carried out. This is, in part, due to the lack of a suitable assay system which can be easily established in a clinical laboratory. Methods involving the spectrophotometric measurement of pyridoxal $^{12}$ lack sensitivity and are unsuitable for use with unpurified tissue homogenate. Sensitive methods have been developed for the assay of pyridoxal phosphate using radiometric assays with apotyrosine decarboxylase ${ }^{1314}$ or apotryptophanase. $^{15}$ However, these assays are technically quite difficult and do not permit the assay of free pyridoxal in the samples. The most sensitive method available for measuring both pyridoxal and pyridoxal phosphate in biological samples is the microbiological assay method using Lactobacillus casei. ${ }^{16}$ Although the method is highly sensitive, it is very time-consuming and requires specialised expertise and equipment not available to the majority of laboratories.

This paper presents a sensitive fluorimetric assay for the estimation of pyridoxal and pyridoxal phosphate in biological samples. The assay is based on hydrolysis of pyridoxal phosphate by acid phosphatase followed by ion-exchange chromatography and oxidation of the pyridoxal to fluorescent 4-pyridoxolactone.

\section{Material and methods}

\section{MATERIAL}

Pyridoxal hydrochloride, pyridoxal phosphate and acid phosphatase (type II from potato), were purchased from Sigma London Ltd. Cation-exchange resin AG50W-X2, 100-200 mesh, $\mathrm{H}^{+}$form, and anion exchange resin $\mathrm{AG} 1-\mathrm{X8}, 100-200$ mesh, $\mathrm{CI}^{-}$ form, were purchased from Bio-Rad Laboratories Ltd. All other reagents were of Analar grade.

\section{METHODS}

Preparation of ion-exchange columns

Anion-exchange column Anion-exchange resin AG1-X8 was washed with 20 vol $1 \mathrm{M} \mathrm{NaOH}$, equilibrated with 2 vol $1 \mathrm{M}$ acetic acid and 
Pyridoxal

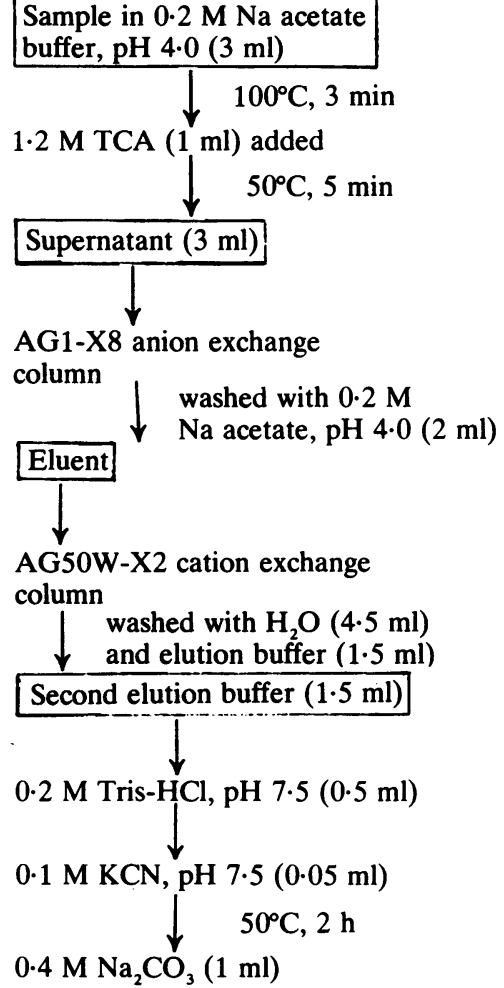

Fig. 1 Flow diagram of assay for measurement of free and total pyridoxal. Pyridoxal phosphate was determined by difference. Further details in methods section. TCA = trichloroacetic acid.

repeatedly washed with distilled water until the effluent was less than $\mathrm{pH} 4 \cdot 0$. A $5 \mathrm{~cm}$ column was prepared in a Pasteur pipette (ID $5 \mathrm{~mm}$ ) plugged with a $4 \mathrm{~mm}$ glass bead.

Cation exchange column Cation-exchange resin AG50W-X2 was equilibrated with $1 \mathrm{M} \mathrm{NaOH}$ and repeatedly washed with distilled water until the effluent was less than $\mathrm{pH} 7 \cdot 0$. A $2 \mathrm{~cm}$ column was prepared in a Pasteur pipette as described for the anion-exchange column. Sodium acetate buffer, 1 $\mathrm{M}, \mathrm{pH} 4 \cdot 0$, was passed through the column until the effluent was $\mathrm{pH} 4 \cdot 0$.

\section{Preparation of samples}

Human polymorphonuclear leucocytes were isolated by dextran sedimentation and Ficoll-Hypaque centrifugation from $50 \mathrm{ml}$ blood as previously described. ${ }^{17}$ The plasma was removed, boiled for 3 min to destroy enzyme activities and retained for analysis. The isolated cells were resuspended in 4.5 $\mathrm{ml} 0.2 \mathrm{M} \mathrm{Na}$ acetate-acetic acid buffer $\mathrm{pH} \mathrm{4.0}$, and
Pyridoxal phosphate

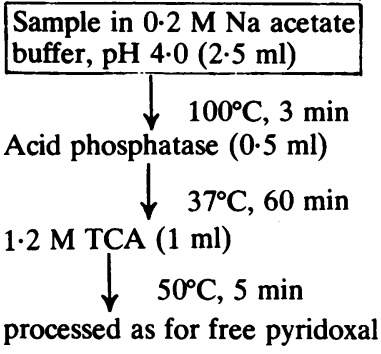

Total pyridoxal measurement disrupted in a Dounce homogeniser by 30 strokes of a tight fitting (type B) pestle. An aliquot was retained for protein determination and the remainder boiled for $3 \mathrm{~min}$.

\section{Estimation of free pyridoxal}

Boiled plasma or neutrophil homogenate $(2 \mathrm{ml})$ was mixed with $0.2 \mathrm{M} \mathrm{Na}$ acetate buffer, $\mathrm{pH} 4.0(1 \mathrm{ml})$, and $1 \mathrm{ml} \mathrm{1.2} \mathrm{M}$ trichloracetic acid. The samples were heated at $50^{\circ} \mathrm{C}$ for $5 \mathrm{~min}$ to ensure complete precipitation of the protein. After centrifugation at $800 \mathrm{~g}$ for $5 \mathrm{~min}$, the supernatant was removed and retained for analysis.

\section{Estimation of total pyridoxal}

Boiled plasma or neutrophil homogenate $(2 \mathrm{ml})$ was added to $0.2 \mathrm{M} \mathrm{Na}$ acetate buffer pH $4.0(1 \mathrm{ml})$ containing 0.34 milliunits of acid phosphatase and incubated at $37^{\circ} \mathrm{C}$ for $60 \mathrm{~min}$. This hydrolysed all the pyridoxal phosphate in the sample to pyridoxal. After cooling, $1 \mathrm{ml} 1.2 \mathrm{M}$ trichloroacetic acid was 


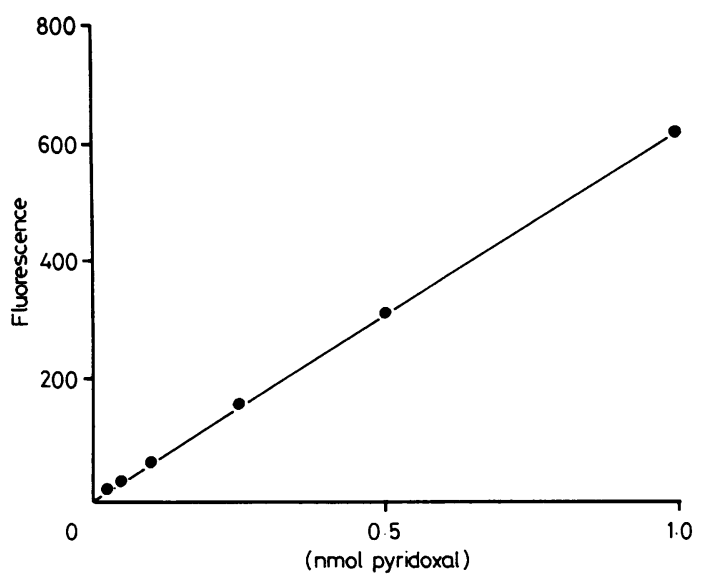

Fig. 2 Calibration curve for fuorescent assay of pyridoxal.
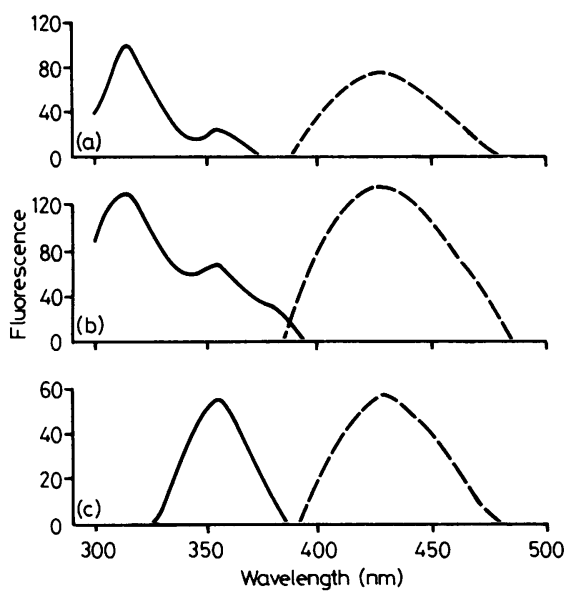

Fig. 3 Excitation (-) and emission (- - ) spectra for (a) neutrophil extract; (b) plasma extract; (c) authentic pyridoxal. The spectra were recorded after treatment with alkaline potassium cyanide.

added and the samples treated exactly as for the estimation of free pyridoxal. The difference between total and free pyridoxal was pyridoxal phosphate.

\section{Fluorimetric determination of pyridoxal in tissue extracts}

The procedure for the measurement of pyridoxal in tissue extracts is outlined in Fig. 1. A previously prepared $5 \mathrm{~cm}$ anion-exchange column was mounted above each cation-exchange column so that the effluent from the first column ran directly onto the second column. An extract of plasma or neutrophils, $3 \mathrm{ml}$, was loaded onto the anion exchange column and eluted with $2 \mathrm{ml} 0.2 \mathrm{M} \mathrm{Na}$ acetate buffer, $\mathrm{pH} 4 \cdot 0$. The eluent from the first column then passed directly onto the cation- exchange column. At this stage the first column was removed and discarded and the cation-exchange column eluted sequentially with $4.5 \mathrm{ml}$ distilled water and with two portions of $1.5 \mathrm{ml} 20 \mathrm{mmol}$ Tris- $\mathrm{HCl}$ containing $0 \cdot 1 \mathrm{M} \mathrm{KCl}, \mathrm{pH} 9 \cdot 0$ (elution buffer). The second $1.5 \mathrm{ml}$ eluate was retained for analysis. To the standards and unknown samples of pyridoxal $(0.025-1.0 \mathrm{nmol}$ in $1.5 \mathrm{ml}$ elution buffer $)$ were added $0.2 \mathrm{M}$ Tris- $\mathrm{HCl}, \mathrm{pH} 7.5(0.5 \mathrm{ml})$ and 0.1 $\mathrm{M} \mathrm{KCN}$ in $0.1 \mathrm{M}$ Tris- $\mathrm{HCl}, \mathrm{pH} 7.5(0.05 \mathrm{ml})$. After thorough mixing, the tubes were heated in the dark for $2 \mathrm{~h}$ at $50^{\circ} \mathrm{C}$ in a Tecam dry bath. After cooling, $0.4 \mathrm{M} \mathrm{Na}_{2} \mathrm{CO}_{3}(1 \mathrm{ml})$ was added to each of the tubes and the fluorescence determined with $355 \mathrm{~nm}$ for excitation and $430 \mathrm{~nm}$ for emission wavelengths. A typical standard curve for the determination of pyridoxal is shown in Fig. 2. Suitable blanks were prepared with each batch of assays.

Fig. 3 compares the excitation and emission spectra of the derivitised authentic pyridoxal and plasma and leucocyte extracts processed for the assay of total pyridoxal. Authentic pyridoxal gives an excitation maximum of $355 \mathrm{~nm}$ with an emission maximum at $430 \mathrm{~nm}$. The processed plasma and leucocyte extracts give excitation maxima at $315 \mathrm{~nm}$ and $355 \mathrm{~nm}$. The emission maximum when excited at $355 \mathrm{~nm}$ was $430 \mathrm{~nm}$. The nature of the compound excited maximally at $315 \mathrm{~nm}$ is unclear. However, it shows an emission maximum at $400 \mathrm{~nm}$ and clearly does not interfere with the fluorimetric measurement of pyridoxal. Similar conclusions were reached for estimation of both free and total pyridoxal in both plasma and neutrophil extracts.

\section{Results}

\section{Hydrolysis of pyridoxal phosphate by acid} phosphatase

A UV-visible spectrum of the conversion of pyridoxal phosphate to pyridoxal by acid phosphatase is shown in Fig. 4. After $60 \mathrm{~min}$ incubation all the pyridoxal phosphate had been hydrolysed to pyridoxal. This sample contained approx 25 -fold the level of pyridoxal phosphate usually found in the tissue extracts.

\section{Anion-exchange column}

The purpose of the anion-exchange column was to remove contaminating substances in the tissue extracts which could interfere with the anion exchange column or the fluorimetric determination of pyridoxal. The major contaminant in the extracts was the trichloroacetic acid added to precipitate the protein. A series of tissue extracts were prepared and adjusted to $\mathrm{pH} 1 \cdot 4$. Each extract was loaded onto anion exchange columns of varying length and 


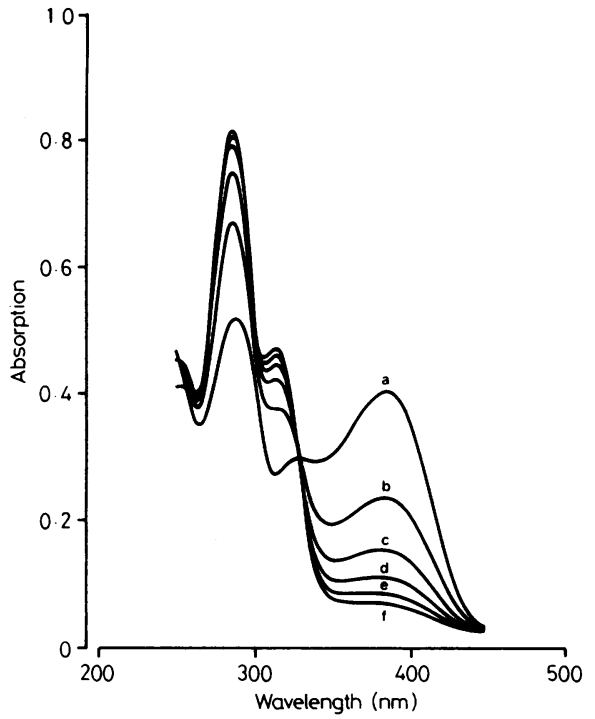

Fig. 4 Sequential UV-visible spectra of pyridoxal released from pyridoxal-5'-phosphate by acid phosphatase.

Pyridoxal-5'-phosphate, $0.25 \mathrm{nmol}$, was incubated at $37^{\circ} \mathrm{C}$ with 0.34 milliunits of acid phosphatase in $0.2 \mathrm{M} \mathrm{Na}$ acetate-acetic acid buffer, pH 4.0. Spectra determined in a Perkin Elmer, model 557, dual beam spectrophotometer at (a) prior to addition of the enzyme, and after (b) $15 \mathrm{~min}$, (c) $30 \mathrm{~min},(d) 45 \mathrm{~min},(e) 60 \mathrm{~min}$ and $(f) 75 \mathrm{~min}$.

the $\mathrm{pH}$ of the eluent measured. All columns less than $4 \mathrm{~cm}$ in length failed to remove the trichloroacetic acid and the $\mathrm{pH}$ of the effluents remained less than $4 \cdot 0$. A $5 \mathrm{~cm}$ column removed all trichloroacetic acid from the sample and the effluent $(\mathrm{pH}$ $4 \cdot 0$ ) was suitable for direct loading onto the cation exchange column.

\section{Cation-exchange column}

Under the conditions of assay pyridoxal forms a highly fluorescent product when oxidised with alkaline potassium cyanide. Unfortunately, pyridoxal phosphate, under the same conditions, also gives rise to a fluorescent product with an emission intensity one-sixth of that produced by pyridoxal. Therefore, in order to accurately assay pyridoxal a separation procedure was required. At pH 4.0 pyridoxal binds to the cation exchange resin whilst pyridoxal phosphate does not. The UVvisible spectra of a typical elution are shown in Fig. 5 . All $(99 \%)$ the pyridoxal was eluted in the second $1.5 \mathrm{ml}$ of elution buffer with no further material present in the subsequent $1.5 \mathrm{ml}$ of elution buffer. The recovery of pyridoxal over the entire procedure was $98-105 \%$. There was no increase in recovery of pyridoxal after the addition of pyridoxal phosphate at the fluorescent step.

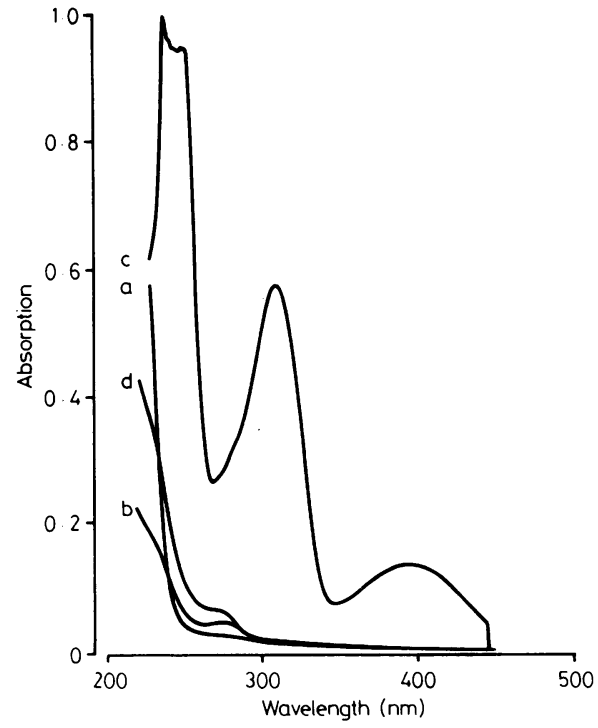

Fig. $5 U V$-visible spectra of eluents from cation-exchange column. Pyridoxal, $0.5 \mathrm{nmol}$ was loaded onto the dual anion-cation exchange columns as described in the text. The cation exchange resin was eluted sequentially with: (a) 4.5 $\mathrm{ml} \mathrm{H}_{2} \mathrm{O}$; (b) $1.5 \mathrm{ml}$ elution buffer (first aliquot); (c) $1.5 \mathrm{ml}$ elution buffer (second aliquot); (d) $1.5 \mathrm{ml}$ elution buffer (third aliquot). Spectra determined in a Perkin Elmer, model 557, dual beam spectrophotometer.

\section{Levels of pyridoxal and pyridoxal phosphate}

Using this assay, the level of pyridoxal and pyridoxal phosphate was measured in plasma and neutrophils from control subjects and a small number of patients with sideroblastic marrow (Table). Note that in plasma pyridoxal is largely present as the free vitamer whereas in neutrophils pyridoxal phosphate is twice the level of pyridoxal. In the patient with pyridoxine-responsive sideroblastic anaemia, the concentrations of both forms of the vitamins in plasma and neutrophils were reduced when compared to control subjects. However, in patients with a sideroblastic marrow associated with alcoholism or preleukaemia who did not respond to pyridoxine therapy the concentrations in neutrophils, with the exception of the pyridoxal in one patient, were normal. In plasma the concentrations of pyridoxal and pyridoxal phosphate varied widely. All sideroblastic patients were treated with pyridoxine (100 $\mathrm{mg}$ daily) and their plasma and neutrophil levels re-estimated after one month of treatment. In all patients the concentrations of pyridoxal and pyridoxal phosphate were raised, although the increase in neutrophils was not as striking as that found in plasma. 
Concentrations of pyridoxal and pyridoxal phosphate in plasma and neutrophils from control subjects and patients with sideroblastic marrow

\begin{tabular}{|c|c|c|c|c|c|c|c|}
\hline \multirow[t]{2}{*}{ Patient } & \multirow{2}{*}{$\begin{array}{l}\text { Haematological } \\
\text { response to } \\
\text { pyridoxine }\end{array}$} & \multicolumn{3}{|l|}{ Plasma } & \multicolumn{3}{|l|}{ Neutrophils } \\
\hline & & Pyridoxal & $\begin{array}{l}\text { Pyridoxal } \\
\text { phosphate }\end{array}$ & Total & Pyridoxal & $\begin{array}{l}\text { Pyridoxal } \\
\text { phosphate }\end{array}$ & Total \\
\hline $\begin{array}{l}\text { Pretreatment } \\
\text { A } \\
\text { B } \\
\text { C } \\
\text { D }\end{array}$ & $\begin{array}{l}\text { Yes } \\
\text { No } \\
\text { No } \\
\text { No }\end{array}$ & $\begin{array}{c}<0.5 \\
23 \cdot 7 \\
2 \cdot 16 \\
17 \cdot 5\end{array}$ & $\begin{array}{c}3.45 \\
<0.5 \\
19 \cdot 5 \\
8.21\end{array}$ & $\begin{array}{l}3.45 \\
23.7 \\
21.6 \\
25.7\end{array}$ & $\begin{array}{l}4 \cdot 19 \\
8 \cdot 14 \\
8 \cdot 69 \\
<1 \cdot 0\end{array}$ & $\begin{array}{r}3.6 \\
15.7 \\
13.0 \\
16.9\end{array}$ & $\begin{array}{l}7.79 \\
23 \cdot 8 \\
21.7 \\
16.9\end{array}$ \\
\hline $\begin{array}{l}\text { On treatment } \\
\text { A } \\
\text { B } \\
\text { D } \\
\text { Control subjects } \\
\text { (mean } \pm \text { SD) }(5) \\
\text { Normal range }\end{array}$ & & $\begin{array}{l}133 \\
304 \\
46 \cdot 2 \\
14 \pm 9 \cdot 6 \\
5 \cdot 5-30 \cdot 0\end{array}$ & $\begin{array}{l}382 \\
51 \cdot 8 \\
23 \cdot 6 \\
5 \cdot 60 \pm 6 \cdot 7 \\
0-16 \cdot 4\end{array}$ & $\begin{array}{l}515 \\
356 \\
69 \cdot 6 \\
20 \cdot 0 \pm 6 \cdot 6 \\
10 \cdot 0-30 \cdot 0\end{array}$ & $\begin{array}{l}16 \cdot 4 \\
34 \cdot 2 \\
26 \cdot 3 \\
7 \cdot 6 \pm 2 \cdot 5 \\
4 \cdot 0-10 \cdot 3\end{array}$ & $\begin{array}{l}34 \cdot 8 \\
27 \cdot 7 \\
30 \cdot 0 \\
13 \cdot 4 \pm 8 \cdot 1 \\
3 \cdot 2-23 \cdot 2\end{array}$ & $\begin{array}{l}51 \cdot 5 \\
61 \cdot 9 \\
56 \cdot 3 \\
20 \cdot 6 \pm 8 \cdot 6 \\
12 \cdot 6-33 \cdot 5\end{array}$ \\
\hline
\end{tabular}

Concentrations in plasma are expressed as $\mathrm{pmol} / \mathrm{ml}$ and in neutrophils as $\mathrm{pmol} / \mathrm{mg}$ protein.

\section{Discussion}

The present study has shown that pyridoxal and pyridoxal phosphate concentrations can be reliably measured in plasma and neutrophils by this fluorimetric technique. The assay is highly sensitive and can be established in any laboratory without the need for specialised equipment or techniques and is clearly applicable to the study of pyridoxal and pyridoxal phosphate metabolism in a variety of clinical conditions. Although the importance of pyridoxal phosphate in metabolism is well established, little is known about its role in disease. As well as being implicated in certain patients with sideroblastic anaemia, ${ }^{7818}$ a deficiency of pyridoxal phosphate has also been associated with such diverse conditions as arteriosclerosis, ${ }^{19}$ convulsions, ${ }^{20}$ toxaemia of pregnancy, ${ }^{21}$ alcoholism ${ }^{910}$ and liver disease. ${ }^{11}$ A simple method for investigating the concentrations of both plasma and tissue pyridoxal and pyridoxal phosphate would be of considerable use in the further investigation of these conditions. In this preliminary study of patients with sideroblastic marrows it seems likely that this could be useful in the diagnosis of responsive and nonresponsive sideroblastic anaemia.

We are grateful to Dr GD. Smith for helpful discussion.

\footnotetext{
References

' Spector R, Greenwald $L$. Transport and metabolism of vitamin $\mathrm{B}_{6}$ in rabbit brain and choroid plexus. $J$ Biol Chem 1978;253:2373-9.

${ }^{2}$ Merrill AH, Moriike K, McCormick DB. Evidence for the regulation of pyridoxal 5-phosphate formation in rat liver by pyridoxamine 5-phosphate oxidase. Biochim Biophys Res Commun 1978;83:984-90.

${ }^{3}$ Anderson BB, Newmark PA, Rawlins M, Green R. Plasma binding of vitamin $B_{6}$ compounds. Nature 1974;250:502-4.

${ }^{4}$ Lumeng L, Cleary RE, Li TK. Effect of oral contraceptives on
}

the plasma concentration of pyridoxal phosphate. Am J Clin Nutr 1974;27:326-33.

' Li TK, Lumeng L, Veitch RL. Regulation of pyridoxal 5'phosphate metabolism in liver. Biochem Biophys Res Commun 1974;61:677-84.

- Smith GP, Peters TJ, Subcellular localization and properties of pyridoxal phosphate phosphatases of human polymorphonuclear leukocytes and their relationship to acid and alkaline phosphatase. Biochim Biophys Acta 1981;661:287-94.

' Hines JD. Effect of pyridoxine plus chronic phlebotomy on the function and morphology of bone marrow and liver in pyridoxine-responsive sideroblastic anaemia. Sémin Hematol 1976;13:133-40.

${ }^{8}$ Solomon LR, Hillman RS. Vitamin $B_{6}$ metabolism in idiopathic sideroblastic anaemia and related disorders. $\mathrm{Br} \mathrm{J}$ Haematol 1979; 42:239-53.

${ }^{9}$ Leevy CM, Baker H, Tenhove W, Frank O, Cherrick GR. B-complex vitamins in liver disease of the alcoholic. Am J Clin Nutr 1965;16:339-43.

${ }^{10}$ Lumeng L, Li TK. Vitamin $\mathrm{B}_{6}$ metabolism in chronic alcohol abuse. J Clin Invest 1974;53:693-704.

"French SW, Castagna J. Some effects of chronic ethanol feeding on vitamin $B_{6}$ deficiency in the rat. Lab Invest 1967;16:526-31.

${ }^{12}$ Turner JM. Pyridoxal phosphate breakdown by an alkaline phosphatase preparation. Biochem J 1961;80:663-8.

${ }^{13}$ Sundaresen PR, Coursin BB. Microassay of pyridoxal phosphate using L-tyrosine-( $\left({ }^{14} \mathrm{C}\right)$ and tyrosine apodecarboxylase. Methods Enzymol 1979;18:509-12.

14 Bhagavan HN, Koogler HM Jr, Coursin DB. Enzymatic microassay of pyridoxal-5-phosphate using L-tyrosine apodecarboxylase. Int J Vit Nutr Res 1976;46:160-4.

is Okuda K, Fujii S, Wada M. Microassay of pyridoxal phosphate using tryptophan ${ }^{14} \mathrm{C}$ with tryptophanase. Methods Enzymol 1970;18A:505-9.

${ }^{16}$ Anderson BB, Peart MB, Fulford-Jones CE. The measurement of serum pyridoxal by a microbiological assay using Lactobacillus casei. J Clin Pathol 1970;23:232-42.

${ }^{17}$ Rustin GJS, Peters TJ. Studies on the subcellular organelles of neutrophils in chronic granulocytic leukaemia with special reference to alkaline phosphatase. $\mathrm{Br} J$ Haematol 1979;41:533-43.

18 Hines JD, Cowan DH. Studies on the pathogenesis of alcoholinduced sideroblastic bone-marrow abnormalities. $N$ Engl $J$ Med 1970;283:441-6.

19 Rinehart JF, Greenberg LD. Arteriosclerotic lesions in pyridoxine-deficient monkeys. Am J Pathol 1949;25:48191.

${ }^{20}$ Heeley A, Pugh RJP, Clayton BE, Shepherd J, Wilson J. 
Pyridoxal metabolism in vitamin $\mathbf{B}_{6}$-response convulsions of early infancy. Arch Dis Child 1978;53:794-802.

${ }^{21}$ Brophy MH, Siiteri PK. Pyridoxal phosphate and hypertensive disorders of pregnancy. Am J Obstet Gynecol 1975;121:1075-9.
Requests for reprints to: Dr Gillian P Smith, Division of Clinical Cell Biology, Clinical Research Centre, Watford Road, Harrow, Middlesex HA1 3UJ.

\section{The May 1983 issue}

\section{THE MAY 1983 ISSUE CONTAINS THE FOLLOWING PAPERS}

Middle Eastern intestinal lymphoma: a morphological and immunohistochemical study P ISAACSON, HS AL-DEWACHI, DY MASON

Raised 5-hydroxytryptamine concentrations in enterochromaffin cells in adult coeliac disease $\mathrm{L}$ ENERBÄCK, C HALLERT, K NORRBY

Benign mesenchymoma of the stomach MT HAQQANI, N KRASNER, M ASHWORTH

Polyamines in colorectal cancer-a clinical and experimental approach R CARACHI, JG BEELEY

Histology of rectal gonorrhoea in men, with a note on anorectal infection with Neisseria meningiti-

dis A McMILLAN, G McNEILlAGE, HM GILMOUR, FD LEE

Angiosarcoma developing around a foreign body JA HAYMAN, H HUYGENS

Muscle morphology and metabolism in hypothyroid myopathy: effects of treatment AA KHALEELI, $K$ GOHIL, G McPHAIL, JM ROUND, RHT EDWARDS

Use of flexible plastic film isolators in performing potentially hazardous necropsies PC TREXLER, AM GILMOUR

Detection of immunoglobulins $G$ and $A$ on the cell membrane of hepatocytes from patients with alcoholic liver disease A TREVISAN, R CAVIGLI, R MELICONI, GF STEFANINI, S ZOTTI, M RUGGE, F NOVENTA, C BETTERLE, G REALDI

Towards an automated procedure for the quantitative cytological screening of cervical neoplasms AM SINCOCK, J MIDDLETON, D MONCRIEFF

Transferrin receptors in human tissues: their distribution and possible clinical relevance KC GATTER, G BROWN, IS TROWBRIDGE, RITA-ELIZABETH WOOLSTON, DY MASON

Histopathology of the lung after bone marrow transplantation JP SLOANE, MH DEPLEDGE, RL POWLES, GR MORGENSTERN, BS TRICKEY, PJ DADY

Membrane Fc-IgG and C3b receptors on myeloid leukaemia cells: a comparison with cytoplasmic acid naphthyl acetate esterase cytochemistry CS SCOTT, AG BYNOE, DC LINCH, C ALLEN, D HOUGH, BE ROBERTS

Lymphoma-like presentation of acute monocytic leukaemia BARBARA BAIN, A MANOHARAN, I LAMPERT, C MCKENZIE, D CATOVSKY

Prevalence and distribution of ringed sideroblasts in primary myelodysplastic syndromes SK JUNEJA, $M$ IMBERT, F SIGAUX, H JOUAULT, C SULTAN

Preoperative antithrombin III activities and lipoprotein concentrations as predictors of venous thrombosis in patients with fracture of neck of femur JH WINTER, A FENECH, B BENNETT, AS DOUGLAS

Freeze dried cryoprecipitate: a clinical evaluation H HAMBLEY, JF DAVIDSON, ID WALKER, M SMALL, CRM PRENTICE

Incidence of infection with hepatitis B virus in $\vec{\oplus}$ 56 patients with haemophilia A 1971-1979 ML STIRLING, JA MURRAY, P MACKAY, SH BLACK, JF PEUTHERER, CA LUDLAM

Enzyme-linked immunosorbent assay (ELISA) for the detection of hepatitis Be antigen and antibody: report of a field trial E MARGARET SUPRAN, ELIZABETH H BOXALL, J CRASKE, RJC HART, ELISE M VANDERVELDE, PS GARDNER

Comparison of the effects of filtration leucapheresis and discontinuous flow centrifugation leucapheresis on granulocyte microbicidal function $S$ MARTIN, ATM GHONEIM, EAE ROBINSON, JA CHILD

A selective medium for Pasteurella multocida and its use with animal and human specimens DP KNIGHT, JANE E PAINE, DCE SPELLER

Comparative study of subculture, Gram staining and acridine orange staining for early detection of positive blood cultures G MASCART, F BERTRAND, $P$ MASCART

Measurement of bilirubin, cholesterol and creatinine in serum and plasma, by solid-phase reflectance spectroscopy JF STEVENS, W TSANG, RG NEWALL

\section{Technical method}

Purification of Toxoplasma gondii from host cells RJ DAHL, AM JOHNSON

\section{Letters to the Editor}

Book reviews

Some new titles

Copies are still available and may be obtained from the PUBLISHING MANAGER.

BRITISH MEDICAL ASSOCIATION, TAVISTOCK SQUARE, LONDON WC1H 9JR. price $£ 5 \cdot 00$, including postage 